Kong. Res. J. 1(2): 112-115, 2014

Kongunadu Arts and Science College, Coimbatore

\title{
PHARMACOGNOSTICAL AND PRELIMINARY PHYTOCHEMICAL SCREENING OF THE LEAVES OF KEDROSTIS FOETIDISSIMA (JACQ.)COGN.
}

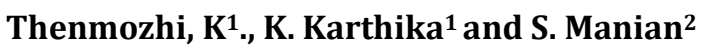

${ }^{1}$ Department of Botany, Kongunadu Arts and Science College, Coimbatore, Tamil Nadu, India. ${ }^{2}$ Department of Botany, Bharathiar University, Coimbatore, Tamil Nadu, India.

E.mail: thenmozhi_05@yahoo.co.in

\section{ABSTRACT}

The objective of the study is to cover the pharmacognostical and preliminary phytochemical screening of traditional medicinal plant, Kedrostis foetidissima belonging to the family Cucurbitaceae. This study includes organoleptic characters, physico-chemical analysis, fluorescence analysis, behaviour of leaf powder with different chemical reagents, phytochemical extraction, extractive yield and qualitative phytochemical screening. The preliminary screening revealed the presence of alkaloids, flavonoids, steroids, tannins, phenolics, glycosides, carbohydrates, proteins and aminoacids which explains that the plant must have valuable medicinal properties and so it can be explored.

Keywords: Kedrostis foetidissima, pharmacognostical and preliminary phytochemical screening.

\section{INTRODUCTION}

Medicinal plants provide an excellent source for valuable drugs. They have curative properties due to the presence of various secondary metabolites like phenolics, tannins, flavonoids, steroids, terpenes etc. Pharmacognostic study is the preliminary step in the standardization of crude drugs. It deals with the authentication and quality assessment of crude plant and herbal material based on macroscopic and microscopic characters (Heinrich, 2000). Evaluation of plant materials and their derived products are important in the field of discovery of phytopharmaceuticals (Sethiya et al., 2010).

Kedrostis foetidissima is a traditional medicinal plant belongs to the family Cucurbitaceae. The fresh leaves are given orally to treat cattle suffering from both pasture and frothy bloats. (Kokwaro and John, 2009). Fruits are given internally in case of colic and abdominal pain. Roots externally applied with bark of Pittosporum floribundum for the treatment of piles. (Pullaiah, 2006). Crude leaf juice is given orally to treat common cold in children (Karuppusamy, 2007). The Zay people in Ethiopia were used this whole plant for curing the chest pain in human beings (Giday, 2001).

The present work deals with the pharmacognostic evaluation of the leaf material of K. foetidissima and establishment of its quality parameters, including phytochemical evaluation.

\section{MATERIALS AND METHODS}

\subsection{Procurement and preparation of plant material}

Fresh leaves of Kedrostis foetidissima were harvested from the surrounding areas of Coimbatore district, Tamil Nadu, India. The authenticity of the selected plant material was duly identified and confirmed by comparison with reference specimens preserved in the herbarium at Botanical Survey of India, Southern Circle, Coimbatore. The collected leaves were washed thoroughly with tap water, shade dried, homogenized to fine powder and stored in air tight bottle.

\subsection{Pharmacognostic studies}

\subsubsection{Organoleptic evaluation}

The plant powder was tested for colour, texture, odour and taste by following the method adopted by Jackson and Snowdown (1968).

\subsubsection{Physicochemical parameters}

The physicochemical parameters like moisture content, total ash content, acid insoluble and water soluble ash contents were determined as per WHO guidelines and using standard procedures (Trease and Evans, 1983; WHO, 2002).

\subsubsection{Fluorescence analysis}

The fluorescence properties of various extracts were studied in visible and ultra violet light (Kokoshi et al., 1958).

\subsubsection{Behaviour of drug powder}

The powdered leaf samples were treated with different reagents and the colour developed was observed under room condition (Brain and Turner, 1975). 


\subsection{Phytochemical studies}

\subsubsection{Extractive yield}

The air dried leaves were exhaustively extracted with successive solvent extraction using soxhlet apparatus viz., petroleum ether, benzene, chloroform, ethyl acetate, ethanol and hot water was performed as per Indian Pharmacopoeia (Peach and Tracey, 1955). The extracts were filtered and concentrated to dryness under reduced pressure using rotary vacuum evaporator (RE 300; Yamato, Japan), Lyophilized (4KBTXL - 75; Vir Tis Benchtopk, New York, USA) to remove traces of water molecules and their extractive yield percentage was calculated.

\subsubsection{Qualitative phytochemical evaluation}

Phytochemical screening for crude solvent extracts were carried out and their bioactive compounds were determined using standard methods (Brain and Turner, 1975; Trease and Evans, 1983; Harborne, 1984).

\section{RESULTS AND DISCUSSION}

Pharmacognostic studies generally encompass organoleptic characters, physicochemical analysis, fluorescence analysis and behaviour of leaf powder with different chemical reagents, all leading to the proper identification and authentification of the medicinal plants under study (Trease and Evans, 1985). In the present study, the organoleptic characters of the leaf powders (Table 1) showed that it is pale green in colour, coarsely powdered, bitter taste and having characteristic odour.

Table 1. Organoleptic characters of Kedrostis foetidissima leaf powder

\begin{tabular}{ccc}
\hline S.No & Character & Observation \\
\hline 1. & Colour & Pale green \\
2. & Texture & Coarse powder \\
3. & Taste & Bitter \\
4. & Odour & Characteristic odour \\
\hline
\end{tabular}

The data on physico chemical characters of $K$. foetidissima leaves were presented in Table 2 and the leaves exhibited more moisture content of $87 \%$. The total ash content was observed to be $9.22 \%$.

However, acid insoluble ash recorded higher value of $3.10 \%$ than the water soluble ash $(0.34 \%)$. Moisture

content of drugs could be at minimal level to discourage the growth of bacteria, yeast or fungi during storage. The total ash values are used to determine quality and purity of crude drug. It indicates the presence of various impurities like carbonate, oxalate and silicate. The acid insoluble ash measures the amount of silica, especially sand which indicates the presence of earthy materials in the sample. The water soluble ash is used to estimate the amount of inorganic compounds present in drugs (Thomas et al., 2008; Vaghasiya et al., 2008; Dave et al., 2010)

\section{Table 2. Physico-chemical analysis of Kedrostis} foetidissima leaves

\begin{tabular}{ccc}
\hline S.No & Parameter & Percentage \\
\hline 1. & Moisture content & 87 \\
2. & Total ash & 9.22 \\
3. & Acid insoluble ash & 3.10 \\
4. & Water soluble ash & 0.34 \\
\hline
\end{tabular}

Extractive yield percentage and fluorescence analysis for different solvent extracts of $K$. foetidissima leaves were calculated (Table 3). The hot water and ethanol extracts registered maximum yield of 10.18 and $8.7 \%$ respectively. This kind of study helps in identifying the chemical entities favouring high percentage yield of the extraction (Kokate, 1995). The extractive values are useful to evaluate the chemical constituents present in the crude drug and also help in the estimation of specific constituents soluble in particular solvent (Thomas et al., 2008). The fluorescence analysis was made both in ordinary and UV lights. This would offer guidance for further identification and confirmation of this plant.

Table 3. Extractive yield, fluorescence analysis of Kedrostis foetidissima leaf extracts under ordinary and UV lights.

\begin{tabular}{|c|c|c|c|c|}
\hline \multirow[t]{2}{*}{ S.No } & \multirow[t]{2}{*}{ Solvents } & \multirow{2}{*}{$\begin{array}{l}\text { Extractive } \\
\text { yield (\%) }\end{array}$} & \multicolumn{2}{|c|}{$\begin{array}{l}\text { Colour by fluorescence } \\
\text { analysis }\end{array}$} \\
\hline & & & $\begin{array}{c}\text { Ordinary } \\
\text { light }\end{array}$ & UV light \\
\hline 1. & $\begin{array}{c}\text { Petroleum } \\
\text { ether }\end{array}$ & 3.7 & $\begin{array}{c}\text { Yellowish } \\
\text { green }\end{array}$ & $\begin{array}{l}\text { Parrot } \\
\text { green }\end{array}$ \\
\hline 2. & Benzene & 1.7 & Brownish & $\begin{array}{c}\text { Flourescent } \\
\text { greenish } \\
\text { brown }\end{array}$ \\
\hline 3. & Chloroform & 0.8 & $\begin{array}{c}\text { Dark } \\
\text { brown }\end{array}$ & $\begin{array}{l}\text { Greenish } \\
\text { black }\end{array}$ \\
\hline 4. & Ethylacetate & 1.1 & $\begin{array}{c}\text { Brownish } \\
\text { green }\end{array}$ & $\begin{array}{l}\text { Greenish } \\
\text { brown }\end{array}$ \\
\hline 5. & Ethanol & 8.5 & $\begin{array}{l}\text { Golden } \\
\text { brown }\end{array}$ & $\begin{array}{c}\text { Fluorescent } \\
\text { greenish } \\
\text { brown }\end{array}$ \\
\hline 6. & $\begin{array}{c}\text { Hot water (by } \\
\text { maceration) }\end{array}$ & 10.18 & $\begin{array}{l}\text { Light } \\
\text { green }\end{array}$ & $\begin{array}{l}\text { Parrot } \\
\text { green }\end{array}$ \\
\hline
\end{tabular}

The behavioural patterns of powdered leaf of $K$. foetidissima with different chemical reagents were examined and tabulated (Table 4). These chemical tests showed the path for isolation of different active constituents present in this plant. 
Marjorie, M.C. (1999). Plant product as antimicrobial agents. Clinical Microbiology reviews. 12: 564582.

Peach and M.V. Tracey, (1955). Modern Methods of Plant Analysis, Vol. III, Springer and Verlag, Berlin. 321-322.

Pullaiah, T. (2006). Biodiversity of India, Regency publications, New Delhi, India. pp 235.

Thomas, S., D.A. Patil, A.G. Patil and N. Chandra, (2008). Pharmacognostic evaluation and physicochemical analysis of Averrhoa carambola L. fruit. Journal of Herbal Medicine and Toxicology. 2:51-54.
Trease, G.E. and W.C. Evans, (1983). Pharmacognosy $12^{\text {th }}$ Ed. Bailliere Tindall, London. pp 622.

Trease, K. And W.C. Evans, (1985). Textbook of pharmacognosy. $12^{\text {th }} \mathrm{Ed}$, Balliere Tindall Publication, London. 537-541.

Vaghasiya, Y., R. Nair and S. Chanda, (2008). Antibacterial and preliminary phytochemical and physico-chemical analysis of Eucalyptus citriodora Hk leaf. Natural Product Research. 22: 754-762.

WHO. (2002). Quality Control Methods for Medicinal Plant Materials. (An authorized publication of World health organization, Geneva). A.I.T.B.S. Publishers \& Distributors, New Delhi. 